\title{
Growth Characteristics of Staphylococcus aureus and Escherichia coli in Whey from Sequentially Infected Milk
}

\author{
By Tiina Mattila-Sandholm, Terhi Alivehmas, Liisa Kaartinen and \\ Tuula Honkanen-Buzalski \\ Food Research Laboratory, Technical Research Centre, Espoo, \\ Department of Pharmacology and Toxicology, College of Veterinary Medicine, Helsinki, and \\ National Veterinary Institute, Helsinki, Finland.
}

\begin{abstract}
Mattila-Sandholm, T., T. Alivehmas, L. Kaartinen and T. Honkanen-Buzalski: Growth characteristics of Staphylococcus aureus and Escherichia coli in whey from sequentially infected milk. Acta vet. scand. 1990, 31, 169-174. - The growth of Staphylococcus aureus and Escherichia coli was followed in bovine whey samples which had been prepared from milk previously incubated with cultures of $S$. aureus or E. coli. Staphylococcal strains were divided into 2 groups according to their ability to form compact or diffuse colonies on serum soft agar, which is related to the absence or presence of capsule respectively. The growth of compact staphylococci was dependent on the bulk tank milk used whereas diffuse colony forming staphylococci grew equally well in all bulk milk, also in all inoculated milk. The growth of E. coli was markedly enhanced in whey samples prepared from milk preincubated with staphylococci. However, clear growth inhibition was seen with $E$. coli and $S$. aureus strains when grown in whey prepared from milk preincubated with $E$. coli. Results indicate that the growth promotion of pathogens due to compositional changes in milk are of importance during the course of infection because the growth pattern on staphylococci is dependent on these compositional changes. The growth-inhibitory effects caused by E.coli may explain difficulties in isolating this organism.
\end{abstract}

bacterial growth; mastitis; capsule.

\section{Introduction}

Studies concerning bacterial interactions in milk have shown that various micro-organisms can antagonize and inhibit the growth of others (Corbeil et al. 1985, Hogan et al. 1987, Woodward et al. 1987). This may explain the role of bacterial interaction in the course of udder infection. Mastitis pathogens are usually isolated as monocultures rather than mixed infections. Some organisms are able to inhibit the growth of others owing to competitive growth. Different inhibitory metabolites, including long-chain fatty acids, produced by patho- gens and nonpathogens have been discussed by Hogan et al. (1987). Inhibitory effects have mainly been studied between pathogens and non-pathogens whereas the growth responses within various pathogenic species have received little attention (Woodward et al. 1987).

Other studies have shown, however, that infection and inflammation in the mammary gland lead to compositional changes in milk which enhance the growth of pathogens, although all the antibacterial factors increase (Reiter 1978, Mattila et al. 1984a \& b, Malkamäki et al. 1986). Mastitic pathogens 
must overcome various antibacterial factors present in milk and under adverse conditions the nutritive quality of the growth medium becomes important. Products of casein hydrolysis and heme compounds are probably the key nutrients for bacteria which are enriched in milk (Kaartinen \& Sandholm 1987, Mattila et al. 1984a \& b). The rise in all the antibacterial factors in milk cannot tilt the host-microbe balance in favour of the host because of increased replication rates of mastitic pathogens. Therefore the growth promotion of pathogens due to bacterial resistance and compositonal changes in milk are of key importance during the course of infection and also in the infection process (Mattila et al. 1984a).

The diffuse and compact colony appearance of staphylococci has been thought to indicate capsule formation and also glycocalyx formation in vivo in the former type (Yoshida 1971, Caputy \& Costerton 1982, Opdebeek et al. 1987). The bacterial capsule material and glycocalyx are known to give protection against many endogenous antibacterial factors (Christensen et al. 1982, Marrie \& Costerton 1981).

The purpose of this study was to determine how the growth of one pathogenic organism in milk may affect the growth of the consecutive pathogens using compact and diffuse colony forming strains of Staphylococcus aureus and a single strain of Escherichia coli. Compact and diffuse strains of staphylococci were studied to observe the effect of the capsule.

\section{Material and methods}

\section{Test organisms}

Five strains of $S$. aureus (QLD 21, 22, 23, $24,26)$ capable of forming diffuse colonies on serum soft agar and 4 strains of $S$. aureus (QLD 5, 6, 7, 9) forming compact colonies on serum soft agar were selected for the growth experiments (Yoshida 1971). The bacteria had been isolated from clinical cases of mastitis and were kindly given to us by $\operatorname{Dr}$ A. Frost, University of Quensland, Australia. E. coli (strain EKK 64) was isolated from a cow having acute mastitis.

\section{Quarter milk samples}

Quarter milk samples from a healthy Ayshire cow was used. The quarter milk was checked for $3 \mathrm{~d}$ for somatic cell count (SCC) and presence of bacteria before collection. The SCC was $<200,000 / \mathrm{ml}$ and bacteria were absent from samples used.

\section{Bulk milk}

Three bulk milk samples were obtained at separate time intervals from a farm with 25 Ayshire cows having a good udder health records. The SCC of the bulk tank milk ranged from 150,000 to $200,000 / \mathrm{ml}$.

\section{In vitro inoculation of milk}

Quarter milk samples and the bulk milk were inoculated and preincubated with bacteria as follows: fresh overnight bovine blood agar cultures of test bacteria were suspended in physiological saline to yield a suspension of $10^{7} \mathrm{cfu} / \mathrm{ml}$. Milk was divided into $9 \mathrm{ml}$ portions and $1 \mathrm{ml}$ bacterial suspension was added to each aliquot. The milk samples were then incubated at $37^{\circ} \mathrm{C}$ in a water bath for $4 \mathrm{~h}$ under continuous shaking.

\section{Whey preparation from inoculated milk}

After defatting of the preincubated milk samples, whey was prepared by centrifuging at $45,000 \mathrm{G}$ for $60 \mathrm{~min}$ at $4^{\circ} \mathrm{C}$. Whey samples were sterile-filtered $(0.45 \mu \mathrm{m}$, Millipore) before analysing their quality as growth media for E. coli and S. aureus. 
Bacterial growth in whey

Bacterial suspensions were calibrated with Multiskan microplate reader (Eflab Oy, Helsinki, Finland) to give an initial turbidity of 0.10 before inoculation (corresponds to $10^{7}$ $\mathrm{cfu} / \mathrm{ml}$ ). Bacterial growth was followed by an automated growth analyser based on vertical turbidometry (Bioscreen, Labsystems Oy, Finland). The analyser used Honeycomb microplates consisting of 100 wells each and 2 plates could be included in 1 incubation run. Each well consisted of $250 \mu \mathrm{l}$ of the sterile-filtered whey and $50 \mu \mathrm{l}$ of bacterial suspension as inoculum. The control wells included the whey sample prepared from milk which had not been preincubated with bacteria. Bacterial growth was monitored every $10 \mathrm{~min}$ for $48 \mathrm{~h}$ at $37^{\circ} \mathrm{C}$. The data were stored in a computer and growth curves were analysed using a special program (Bioscr-100). The area under the growth curve (AUC) within incubation of $40 \mathrm{~h}$ (the mean time-point for the stationary phase in all experiments) was chosen as the parameter to compare bacterial growth responses in the whey samples from milk with various preincubations. The area under the growth curve indicates both the slope and maximum turbidity of the bacterial growth curve. The experiments were performed in parallel.

\section{Results}

Growth responses of $S$. aureus in bulk milk (Table 1) showed that the growth of compact strains of staphylococci was enhanced in whey samples which had been prepared from milk inoculated with compact colony forming staphylococci. The growth of diffuse strains of staphylococci, however, was not enhanced after preincubation with staphylococci or E. coli. Bacterial growth responses were similar in the quarter milk samples. The growth pattern of compact and diffuse colony forming staphylococci showed slight
Table 1. Growth of strains of S.aureus with compact and diffuse colonies in whey prepared from bulk milk inoculated with staphylococci or E. coli.

Mean area under the growth curve (AUC)

\begin{tabular}{|c|c|c|}
\hline $\begin{array}{l}\text { milk } \\
\text { inoculated with }\end{array}$ & $\begin{array}{l}\text { S. aureus } \\
\text { compact }\end{array}$ & $\begin{array}{l}\text { S. aureus } \\
\text { diffuse }\end{array}$ \\
\hline $\begin{array}{l}\text { S. aureus } \\
\text { compact }\end{array}$ & $\begin{array}{l}7.1 \pm 1.0^{*} \\
(\mathrm{n}=46)\end{array}$ & $\begin{array}{l}5.9 \pm 0.8 \\
(n=80)\end{array}$ \\
\hline $\begin{array}{l}\text { S. aureus } \\
\text { diffuse }\end{array}$ & $\begin{array}{l}5.9 \pm 0.5 \\
(\mathrm{n}=58)\end{array}$ & $\begin{array}{l}4.9 \pm 0.3 \\
(n=64)\end{array}$ \\
\hline E. coli & $\begin{array}{l}4.4 \pm 0.5 \\
(n=28)\end{array}$ & $\begin{array}{l}4.2 \pm 0.3 \\
(n=38)\end{array}$ \\
\hline $\begin{array}{l}\text { control } \\
\text { (bulk milk } 1,2,3 \text { ) }\end{array}$ & $\begin{array}{l}5.9 \pm 0.4 \\
(n=28)\end{array}$ & $\begin{array}{l}5.4 \pm 0.4 \\
(n=38)\end{array}$ \\
\hline $\begin{array}{l}\text { control } \\
\text { (bulk milk 1) }\end{array}$ & $\begin{array}{l}1.2 \pm 0.6 \\
(\mathrm{n}=10)\end{array}$ & $\begin{array}{l}7.0 \pm 3.4 \\
(n=12)\end{array}$ \\
\hline
\end{tabular}

* S.E.M. = standard error of mean.
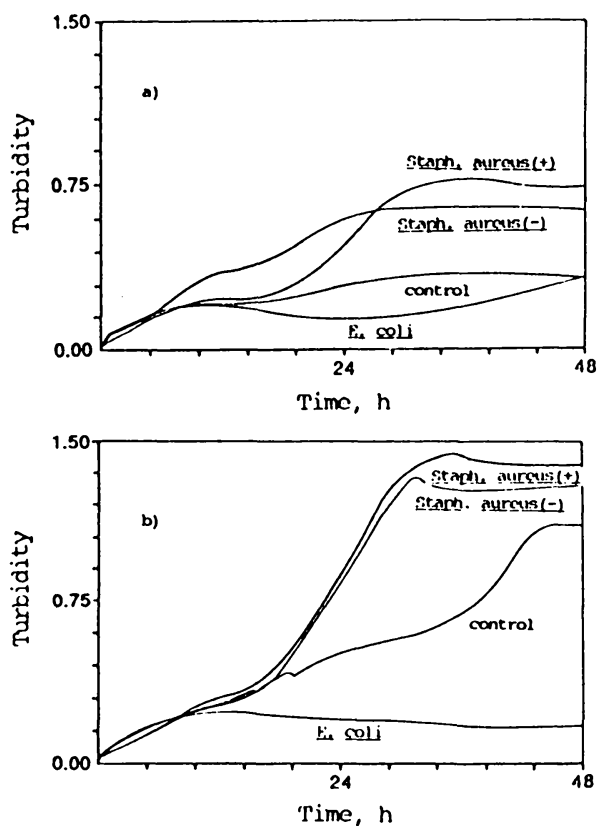

Figure 1. Growth of E.coli in whey prepared from milk samples preincubated with $S$.aureus or E. coli. Control milk was incubated without bacteria. $(t)=S$. aureus forming diffuse colonies, $(-)=S$. aureus forming compact colonies. a) Bulk milk. b) Quarter milk. 
growth inhibition in milk samples preincubated with $E$. coli (Table 1).

The growth of E.coli (Fig. 1) was greatly enhanced in whey samples prepared from milk preincubated with staphylococci. However, the growth of $E$. coli in whey samples prepared from milk preincubated with E. coli was markedly inhibited to levels below those registered in the control whey samples. The coefficient of variation varied from $5-10 \%$ between the curves, which indicates that the differences were significant.

\section{Discussion}

Inflammation of the mammary gland causes compositional shanges in milk which enhances the growth of mastitis pathogens (Mattila et al. 1984a \& b, Malkamäki et al. 1986). This may reflect improved nutritional quality rather than suppressed antibacterial activity. Previous work has shown that the 2 groups af $S$. aureus (compact and diffuse) differ in their ability to grow in mastitic and normal milk (Mattila \& Frost 1988). Those results showed that the growth of compact colony forming staphylococci was significantly enhanced in mastitic whey samples prepared from clinical cases of $S$. aureus and $E$. coli. The growth promotion by mastitic milk was not so evident for diffuse colony forming staphylococci as it was for compact strains. It was concluded that the growth factors present in milk in the mammary gland enhances the growth of the so called naked staphylococci because their metabolic energy is not used to the production of capsule matrix (Mattila \& Frost 1988). The growth in normal whey however was much more evident for diffuse colony forming staphylococci than for compact ones, indicating that normal healthy whey contains less bacterial nutrients and antibacterial factors such as lactoferrin and lactoperoxidase (Reiter 1978).
The results in Table 1 do not indicate differences between the 2 groups of staphylococci if the control values from 3 bulk samples is compared with other samples. However, if the comparison is done towards 1 of the bulk tank samples (bulk tank 1) a clear difference can be seen. Hence the compact colony forming staphylococci showed marked growth promotion with non-inoculated control milks which could not be seen for the diffuse colony forming staphylococci. Otherwise no clear differences between controls of 3 bulk tanks and inoculated milks could be seen. It has to be noted that preparation of control milk in the preincubation studies might give an opportunity for normal milk contaminants to grow because bulk milk is not free of organisms and control milks are not inoculated. Bulk tank 1 contained contaminants only $4 \times 10^{1} / \mathrm{ml}$ on the day of experiment whereas the other bulk milks (bulk milks 2 and 3) contained $10^{3}$ bacteria $/ \mathrm{ml}$ milk. The inoculation of pathogens at a level of $10^{6} / \mathrm{ml}$ prevents any initial contaminants of growing whereas without inoculation contaminants might grow. The growth of any microbe in milk can cause changes in its composition. Furthermore there is a possibility that microbes in bulk milk 2 and 3 may have caused composition changes in milk before the experiments, the growth of psychrothrops in bulk milk surely affects its composition. Previous studies have shown that the compact strains of staphylococci are very sensitive to compositional changes in milk, and therefore they would react "positively" to these compositional changes by growth enhancement (Mattila \& Frost 1988). This could explain why 2 of the bulk tank samples gave higher mean values for compact colony forming staphylococci.

Furthermore milk samples preincubated with E.coli showed growth inhibition for 
both groups of staphylococci. These results seem to be in disagreement with earlier studies where experimental $E$. coli endotoxin milk stimulated the growth of staphylococci (Mattila et al. 1984b). It seems that inflammation of the mammary gland in response to $E$. coli results in production of factors enhancing bacterial growth whereas in the test tube only metabolites inhibiting the growth of bacteria are induced. The inhibitory metabolite could be an antibiotic, bacteriocin or antimetabolite secreted by $E$. coli interfering with the growth of staphylococci and $E$. coli itself. One further explanation could be the consumption of the key nutrient by $E$. coli during preincubation.

The growth of $E$. coli was markedly inhibited in whey prepared from milk preincubated with same $E$. coli. This could give an indication to problems in isolation of $E$. coli in clinical cases of mastitis. Previous studies, however, have shown that in mastitis, pathogenic bacteria do not inhibit their own in vitro growth but the reverse is the case (Mattila et al. 1986). The studies included streptococcal and staphylococcal strains, however E. coli was not included (Mattila et al. 1986).

Nonpathogens such as Corynebacterium and Bacillus species can inhibit the growth of pathogens such as Staphylococci (Woodward et al. 1987). Moreover, most of these studies have been carried out in vitro where either the bacteria have been allowed to interact directly with each other by studying the effects of the metabolites secreted by the non-pathogens (Corbeil et al. 1985, Hogan et al. 1987, Ribble 1967, Woodward et al. 1987). Our results show that pathogenic staphylococci may alter the milk environment to stimulate growth of other pathogens whereas $E$. coli does the reverse. This could give one answer to the unsolved problems with chronic staphylococcal infections.

\section{References}

Caputy GG, Costerton JW: Morphological examination of the glycocalyces of Staphylococcus aureus strains Wiley and Smith. Infect. Immun. 1982, 36, 759-767.

Christensen GD, Simpson WA, Bisno AL, Beachey EH: Adherence of slime-producing strains of Staphylococcus aureus to smooth surfaces. Infect. Immun. 1982, 37, 318-326.

Corbeil LB, Woodward W, Ward AC, Mickelsen $W D$, Paisley $L$ : Bacterial interactions in bovine respiratory and reproductive infections. J. clin. Microbiol. 1985, 21, 803-807.

Hogan JS, Pankey JW, Duthie AH: Growth responses of Staphylococcus aureus and Streptococcus agalactiae to Corynebacterium metabolites. J. Dairy Sci. 1987, 70, 1294-1301.

Kaartinen L, Sandholm M: Regulation of plasmin activation in mastitic milk. J. Vet. Med. B 1987, 34, 42-50.

Malkamäki M, Mattila T, Sandholm M: Bacterial growth in mastitic milk and whey. Zentralbl. Veterinärmed. B 1986, 33, 174-179.

Marrie TJ, Costerton JW: Prolonged survival of Serratia marcescens in chlorhexidine. Appl. Env. Microbiol. 1981, 42, 1093-1 102.

Mattila T, Frost AJ: The growth of diffuse and compact colonies of Staphylococcus aureus in bovine mastitis and normal whey. Microbiol. Immunol. 1988, 32, 667-673.

Mattila T, Maisi P, Sandholm M: Haem compounds as bacterial growth promoters in whey - a possible application in mastitis. Res. Vet. Sci. 1984a, 36, 52-59.

Mattila T, Sandholm M: Milk plasmin, N-acetylb-D-glucosaminidase, and antitrypsin as determinants of bacterial replication rates in whey. J. Dairy Sci. 1986, 69, 670-675.

Mattila T, Syväjärvi J, Sandholm M: Bacterial growth in whey from mastitic and nonmastitic quarters. Amer. J. vet. Res. 1984b, 45, 2504 2506.

Mattila T, Syväjärvi J, Jensen NE, Sandholm M: Determinants of bacterial replication rates in mastitic whey. J. Dairy Res. 1986, 53, 197-202.

Opdepeeck JP, Frost AJ, O'Boyle D, Norcross $N L$ : The expression of capsule in serum soft 
agar by Staphylococcus aureus isolated from bovine mastitis. Vet. Microbiol. 1987, 13, 225 -234 .

Reiter B: Rewiew of the progress in Dairy Science: antibacterial systems in milk. J. Dairy Sci. 1978, 45, 131-147.

Ribble J: A mechanism of bacterial interference in vitro. J. Immunol. 1967, 95, 716-723.

Woodward WD, Besser TE, Ward AC, Corbeil $L B$ : In vitro growth inhibition of mastitic pathogens by bovine teat skin normal flora. Can. J. vet. Res. 1987, 51, 27-31.

Yoshida $K$ : Demonstration of serologically different capsular types among strains of $S$. aureus by the serum-soft agar technique. Infect. Immun. 1971, 3, 535-539.

\section{Sammandrag}

Kännetecken för tillväxt av Staphylococcus aureus och Escherichia coli $i$ vassla från infekterad mjölk

Förökning af Staphylococcus och Escherichia coli i bovin vasslapreparat framställt av mjölk, som tidigare inkuberats med $S$. aureus eller E.coli, uppföljdes. Stafylokocker indelades i två grupper beroende på deras förmåga att bilda täta eller diffusa kolonier på serum soft-agar. Denna förmåga härrör sig från- resp. närvaron av kapslar. Tillväxten hos stafylokocker med täta kolonier berodde på tankmjölk medan stafylokocker med diffusa kolonier förökade sig lika bra oberoende av om man använde tankmjölk eller ympad mjölk. Förökningen av E. coli förbättrades märkbart $\mathrm{i}$ vasslepreparat framställda ur mjölk preinkuberad med stafylokocker. En klar inhibering av tillväxten kunde emellertid observeras för E. coli och $S$. aureus när tillväxten skedde i vasslepreparat från mjölk preinkuberad med E. coli. Resultaten visar att en gynnsam förökning av patogener är beroende av mjölkens sammansättning. Stafylokockerna är ytterst beroende av förändringar $\mathrm{i}$ sammansättningen, speciellt viktigt är detta i samband med infekteringen p.g. a. tillväxtmönstret. De tillväxtinhiberande effekterna förorsakade av E. coli kan eventuellt förklara svårigheterna $\mathrm{i}$ att isolera denna organism.

(Received May 31, 1989; accepted August 17, 1989).

Reprints may be requested from: Tiina Mattila-Sandholm, Food Research Laboratory, Technical Res. Centre, P. O. Box 203, SF-02151 Espoo, Finland. 